\title{
Computed tomography findings of paracoccidiodomycosis in musculoskeletal system*
}

\author{
Aspectos de imagem da paracoccidioidomicose osteoarticular na avaliação por tomografia \\ computadorizada
}

\section{Francisco Valtenor Araújo Lima Júnior ${ }^{1}$, Leonor Garbin Savarese ${ }^{1}$, Lucas Moretti Monsignore ${ }^{2}$, Roberto Martinez $^{3}$, Marcello Henrique Nogueira-Barbosa ${ }^{4}$}

Lima Júnior FVA, Savarese LG, Monsignore LM, Martinez R, Nogueira-Barbosa MH. Computed tomography findings of paracoccidiodomycosis in musculoskeletal system. Radiol Bras. $2015 \mathrm{Jan} / \mathrm{Fev} ; 48(1): 1-6$.

Abstract Objective: To evaluate musculoskeletal involvement in paracoccidioidomycosis at computed tomography.

Materials and Methods: Development of a retrospective study based on a review of radiologic and pathologic reports in the institution database. Patients with histopathologically confirmed musculoskeletal paracoccidioidomycosis and submitted to computed tomography were included in the present study. The imaging findings were consensually described by two radiologists. In order to avoid bias in the analysis, one patient with uncountable bone lesions was excluded from the study.

Results: A total of seven patients were included in the present study. A total of 18 bone lesions were counted. The study group consisted of 7 patients. A total number of 18 bone lesions were counted. Osteoarticular lesions were the first manifestation of the disease in four patients $(57.14 \%)$. Bone lesions were multiple in $42.85 \%$ of patients. Appendicular and axial skeleton were affected in $85.71 \%$ and $42.85 \%$ of cases, respectively. Bone involvement was characterized by well-demarcated osteolytic lesions. Marginal osteosclerosis was identified in $72.22 \%$ of the lesions, while lamellar periosteal reaction and soft tissue component were present in $5.55 \%$ of them. One patient showed multiple small lesions with bone sequestra.

Conclusion: Paracoccidioidomycosis can be included in the differential diagnosis of either single or multiple osteolytic lesions in young patients even in the absence of a previous diagnosis of pulmonary or visceral paracoccidioidomycosis

Keywords: Paracoccidioidomycosis; Osteoarticular; Musculoskeletal; Osteomyelitis; Computed tomography.

Resu mo Objetivo: Avaliar o acometimento musculoesquelético da paracoccidioidomicose nas imagens de tomografia computadorizada.

Materiais e Métodos: Estudo retrospectivo desenvolvido a partir de revisão de laudos radiológicos e patológicos do banco de dados da instituição. Foram selecionados pacientes com paracoccidioidomicose osteoarticular submetidos a tomografia computadorizada. Todos os casos considerados tiveram confirmação histopatológica da doença. Os achados de imagem foram descritos em consenso por dois radiologistas. Um paciente com incontáveis lesões ósseas foi excluído da contabilização das anormalidades com a finalidade de evitar viés. Resultados: Foram incluídos 7 pacientes no presente estudo. Um total de 18 lesões ósseas foi contabilizado. Em quatro casos (57,14\%) a lesão osteoarticular foi a primeira manifestação da doença. As lesões ósseas eram múltiplas em 42,85\%. Os esqueletos apendicular e axial foram afetados em $85,71 \%$ e $42,85 \%$ dos pacientes, respectivamente. O envolvimento ósseo caracterizou-se por lesões osteolíticas bem delimitadas. Identificou-se osteoesclerose marginal em 72,22\% das lesões contabilizadas. Reação periosteal lamelar e componente de partes moles estiveram presentes em 5,55\% das anormalidades. Um paciente exibiu múltiplas lesões com sequestros ósseos. Conclusão: A paracoccidioidomicose pode ser incluída no diagnóstico diferencial de lesões osteolíticas, únicas ou múltiplas, em pacientes jovens, mesmo sem diagnóstico prévio de paracoccidioidomicose pulmonar ou visceral.

Unitermos: Paracoccidioidomicose; Osteoarticular; Musculoesquelético; Osteomielite; Tomografia computadorizada.

* Study developed at Unit of Radiodiagnosis - Centro de Ciências das Imagens e Física Médica (CCIFM) da Faculdade de Medicina de Ribeirão Preto da Universidade de São Paulo (FMRP-USP), Ribeirão Preto, SP, Brazil.

1. MDs, Residents of Radiology and Imaging Diagnosis, Hospital das Clínicas da Faculdade de Medicina de Ribeirão Preto da Universidade de São Paulo (HCFMRPUSP), Ribeirão Preto, SP, Brazil.

2. Physician Assistant at Centro de Ciências das Imagens e Física Médica (CCIFM) da Faculdade de Medicina de Ribeirão Preto da Universidade de São Paulo (FMRPUSP), Ribeirão Preto, SP, Brazil.

3. PhD, Professor, Department of Medical Practice, Faculdade de Medicina de Ribeirão Preto da Universidade de São Paulo (FMRP-USP), Ribeirão Preto, SP, Brazil.

4. PhD, Professor, Centro de Ciências das Imagens e Física Médica (CCIFM) da Faculdade de Medicina de Ribeirão Preto da Universidade de São Paulo (FMRPUSP), Ribeirão Preto, SP, Brazil.

\section{INTRODUCTION}

Paracoccidioidomycosis (PCM) is a systemic mycosis caused the dimorphic fungus Paracoccidioides brasiliensis found in the ground of Latin American countries, particularly in Brazil, Colombia and Venezuela ${ }^{(1-7)}$. About $80 \%$ of cases occur in Brazil, principally in rural zones of the Southern,

Mailing Address: Dr. Francisco Valtenor Araújo Lima Júnior. Faculdade de Medicina de Ribeirão Preto - Universidade de São Paulo. Avenida Bandeirantes, 3900, Campus Universitário. Ribeirão Preto, SP, Brazil, 14049-090. E-mail: fvaltenor@ gmail.com.

Received June 8, 2014. Accepted after revision August 1, 2014. 
Southeastern and Central-western regions where the disease is endemic ${ }^{(4,6,8)}$, but nevertheless no accurate epidemiological data about PCM in Brazil are available, since the disease notification is not compulsory in the country ${ }^{(9)}$.

$P$. brasiliensis infection is acquired by fungal microconidia inhalation ${ }^{(10)}$. The infectious form of the disease affects the inferior airways, resulting in the development of a primary pulmonary complex ${ }^{(2,7,9,11,12)}$. In this phase, lymphohematogenous dissemination of the agent may occur towards other organs and systems, depending on some factors such as number of inoculates, fungus pathogenicity and virulence, as well as integrity of the immunological system and possible genetic factors ${ }^{(2)}$. Most of times, the primary infection recedes spontaneously, and pulmonary and/or fibrotic lymphatic lesions where the fungus may remain for many years in latent state ${ }^{(9,12)}$.

Some infected individuals, particularly children and adolescents of both genders equally, progress to an acute/subacute presentation (juvenile type) of the disease ${ }^{(1,2)}$. Such clinical presentation has a more rapid progression characterized by involvement of the lungs and other tissues such as the skin and mucosas. On the other hand, the chronic presentation (adult type) is related to latent $P$. brasiliensis foci reactivation or a new exposure to the fungus, representing most of cases of the disease (approximately 90\%). Such a presentation predominates in male, adult individuals aged between 30 and $60^{(1,2,10)}$, with an insidious course characterized by involvement of the lungs and other tissues such as the skin and mucosas.

Because of the rarity of bone and joints involvement by PCM, there are few publications on the subject, most of them corresponding to case reports ${ }^{(5-7,13-16)}$. The authors have not found in the literature any article approaching computed tomography imaging findings of the musculoskeletal involvement in PCM.

The present study is aimed at identifying the characteristics of osteoarticular involvement by the disease at CT images by analyzing a series of cases of musculoskeletal in- volvement by PCM, with histopathological confirmation and literature review.

\section{MATERIALS AND METHODS}

Retrospective study previously approved by the Committee for Ethics in Research with Humans of the Institution. In a review of radiology and pathology reports in the databank at the authors' institution, seven cases of patients with histologically confirmed diagnosis of osteoarticular lesions from PCM were found.

The inclusion criteria were the following: a) PCM diagnosis confirmation by a combination of serological (counterimmunoelectrophoresis) and histopathological tests of bone or joints tissues collected by percutaneous biopsy; b) availability of CT images showing evidence of osteoarticular involvement by the fungus.

Clinical data were obtained by means of the medical records review and included the following information: patients' sex, age, clinical classification of PCM, osteoarticular symptoms, as well as presence of involvement of other organs/systems by the disease.

The CT images were retrospectively analyzed by two radiologists of the institution, one of them a senior specialist in musculoskeletal radiology with more than 15 years of subspecialty.

\section{RESULTS}

The present series included seven patients (Table 1), $71.42 \%$ men $(n=5)$ and $28.57 \%$ women $(n=2)$. The patients' age ranged from 10 to 33 years, mean 18.42 years (standard deviation $=7.65$ ). The disease was classified as acute/subacute in six individuals, while only one case was clinically classified as chronic presentation of PCM.

In $57.14 \%$ of the patients there was isolated involvement of the musculoskeletal system $(n=4)$. In all the cases included in the study, the bone tissue was compromised by the disease. Joint alterations (either primary or secondary) were observed in $42.85 \%$ of the patients $(n=3)$. Osteoarticular

Table 1-Characteristics of 7 patients with osteoarticular paracoccidioidomycosis included in the present series.

\begin{tabular}{|c|c|c|c|c|c|c|c|c|}
\hline$P *$ & Sex & $\begin{array}{c}\text { Age } \\
\text { (years) }\end{array}$ & $\begin{array}{c}\text { Clinical } \\
\text { classification }\end{array}$ & Tissues involved & Affected regions & Other affected sites & $\begin{array}{c}\text { Isolated } \\
\text { osteoarticular } \\
\text { involvement }\end{array}$ & $\begin{array}{l}\text { Osteoarticular } \\
\text { symptoms }\end{array}$ \\
\hline 1 & M & 15 & Acute/subacute & Bone & Ulna & - & Yes & Acute elbow pain \\
\hline 2 & $\mathrm{M}$ & 33 & Chronic & Bone & $\begin{array}{c}\text { Multiple (axial and } \\
\text { appendicular skeleton) }\end{array}$ & $\begin{array}{l}\text { Lungs, lymph nodes, skin, } \\
\text { mucosa, abdominal organs }\end{array}$ & No & Diffuse joint pain \\
\hline 3 & $\mathrm{~F}$ & 10 & Acute & Bone, soft tissues & Intermediate cuneiform & - & Yes & $\begin{array}{l}\text { Foot pain following } \\
\text { mild trauma }\end{array}$ \\
\hline 4 & M & 24 & Acute & Bone & Vertebra & $\begin{array}{l}\text { Lymph nodes, skin, mucosa, } \\
\text { abdominal organs }\end{array}$ & No & Asymptomatic \\
\hline 5 & $\mathrm{~F}$ & 21 & Acute & Bone, joint & Hip & - & Yes & Acute hip pain \\
\hline 6 & $\mathrm{M}$ & 10 & Acute & $\begin{array}{l}\text { Bone, joint, soft } \\
\text { tissues }\end{array}$ & Femur & - & Yes & Acute knee pain \\
\hline 7 & $\mathrm{M}$ & 16 & Acute & Bone, joint & $\begin{array}{c}\text { Multiple (axial and } \\
\text { appendicular skeleton) }\end{array}$ & $\begin{array}{l}\text { Lungs, lymph nodes, skin, } \\
\text { abdominal organs }\end{array}$ & No & $\begin{array}{l}\text { Acute shoulder } \\
\text { pain }\end{array}$ \\
\hline
\end{tabular}

\footnotetext{
* Random number attributed to the patient. M, male; F, female.
} 
symptoms were reported by the majority of individuals $(85.71 \% ; n=6)$.

Detected bone abnormalities were single in $57.14 \%$ of cases $(n=4)$ and multiple in $42.85 \%(n=3)$. The appendicular skeleton was affected in $85.71 \%$ of the patients $(n=$ 6 ), while the axial skeleton was affected in $42.85 \%$ deles ( $n$ $=3$ ). There was only one case where the lesions were restricted to the axial skeleton.

A total of 18 bone lesions were studies as regards their characteristics. The bone involvement was characterized by well defined osteolytic lesions with a narrow transition zone ranging between few millimeters to few centimeters, and in $42.85 \%$ of the patients $(n=3)$ the authors observed the presence of fine perilesional reactional osteosclerosis representing $72.22 \%$ (13/18) of the bone lesions. Lamellar periosteal reaction and soft parts components were found in $11.11 \%$ $(2 / 18)$ and $5.55 \%(1 / 18)$ of the studied lesions, respectively. A single patient had multiple lesions with bone sequestrum. The patient 7 on Table 1 presented with acute disease with systemic PCM dissemination and multiple bone lesions. The number of bone lesions was very high, making the abnormalities counting difficult, thus their specific characteristics could not be evaluated.

\section{DISCUSSION}

Osteoarticular involvement in PCM is exceptionally found ${ }^{(3,13-17)}$, affecting between $0.01 \%$ and $0.04 \%$ of the patients $^{(3,15)}$. According to the literature ${ }^{(5,6,17-19)}$, it is most commonly found in the disseminated forms of PCM (acute/ subacute or chronic), affecting up to $20 \%$ of patients. Almost all cases in the present series demonstrated bone involvement in the acute/subacute form of the disease, with predominance in young, male individuals. While the disseminated form of PCM represented $42.85 \%$ of cases, osteoarticular involvement was the single manifestation of the disease in $57.14 \%$ of cases.

Most studies in the literature approaching radiological evaluation of PCM have utilized radiography as primary method in the evaluation of osteoarticular lesions ${ }^{(17-19)}$. Pereira et al. ${ }^{(20)}$ have submitted 14 children with the infection to plain radiography and bone scintigraphy. Three patients had bone lesions identified only by the nuclear medicine examination, possibly representing findings of paracoccidioidomycosis. Thus, such authors have raised the hypothesis of the prevalence of bone lesions in PCM being higher than generally identified, considering that in the clinical routine only symptomatic cases are taken into consideration.

In most cases, and similarly to other infections, fungi remain arrested at vascular networks in bone tissues ${ }^{(7)}$. Bone involvement by contiguity with cutaneous/mucosal lesions is less frequent ${ }^{(18,19)}$. It is known that, virtually, any bone, either in the axial or appendicular skeleton, might be affect by the disease; and the literature reports a higher prevalence of lesions in the thoracic segment and in the shoulder girdle, including the sternum, clavicles, scapulas and ribs ${ }^{(5,18,19,21,22)}$.
In long bones, metaphyseal and epiphyseal regions are the most affected sites ${ }^{(7,17)}$, presumably because the greater local vascularization, with possibility of direct extension of the process into the articular space, which is believed to occur in about $30 \%$ of cases $^{(18)}$. There are few reports of disease restricted to joints where the fungus may spread by lymphohematogenous dissemination ${ }^{(7,18,19)}$.

In the present study, there was predominance of lesion in the appendicular skeleton observed in six out of the seven patients. The axial skeleton was involved in three individuals, two of them with concomitant appendicular involvement. The authors have also observed articular involvement in association with bone lesions in $42.85 \%$ of the patients and no case with isolated articular involvement.

A previous history of either blunt or open trauma preceding osteoarticular manifestations made the fungus dissemination easier in the phase of fungemia ${ }^{(7,18,23)}$, a phenomenon called locus minoris resistentiae ${ }^{(23)}$, which should not be interpreted as an agent inoculation factor.

It is admitted that most PCM bone lesions are asymptomatic ${ }^{(5,7,18,19)}$, representing incidental findings at routine radiological investigations. In a 19-case series approaching osteoarticular PCM, Monsignore et al. ${ }^{(17)}$ have identified symptoms in 12 patients, all of them with acute/subacute disease, suggesting a possible association between such a clinical presentation and the presence of symptoms. Articular lesions from PCM usually present exuberant signs represented by joint edema, local heat, redness and different degrees of functional loss ${ }^{(6,7,18,19)}$.

In the present series, the main CT finding of osteoarticular involvement by PCM was that of well-delimited osteolytic lesions (Figure 1), ranging from few millimeters to some centimeters in size, which is compatible with data in the literature $^{(3,5,17-19)}$. Differently from some studies in the literature ${ }^{(3,5,18)}$, the authors have identified the presence of fine reactive osteosclerosis in the margins of $72.22 \%$ (13/18) of the bone lesions (Figures 2 and 3), and the mean time between the disease onset symptoms and the imaging study was 6.33 months (ranging between 3 and 12 months). Other authors have also identified marginal osteosclerosis in part of bone lesions ${ }^{(14,17,19,23)}$. The authors of the present study assume that their results might be explained, at least partially by the utilization of sectional images and by the CT images high resolution, which may have provided higher sensitivity in the detection of subtle abnormalities as compared with other studies which utilized only plain radiography. In two cases of the present study, the authors found images suggestive of fractures in association with the osteolytic lesions (Figures 1 and 2), another finding that has not been frequently described in association with osteoarticular PCM.

Some publications have described the presence of periosteal reaction associated with bone lesions in few cases ${ }^{(17}$, ${ }^{19,23)}$. In the present study, only one patient with periostitis associated with bone lesions was identified (Figure 1), corresponding to $11.11 \%(2 / 18)$ of the studied lesions. Bone 


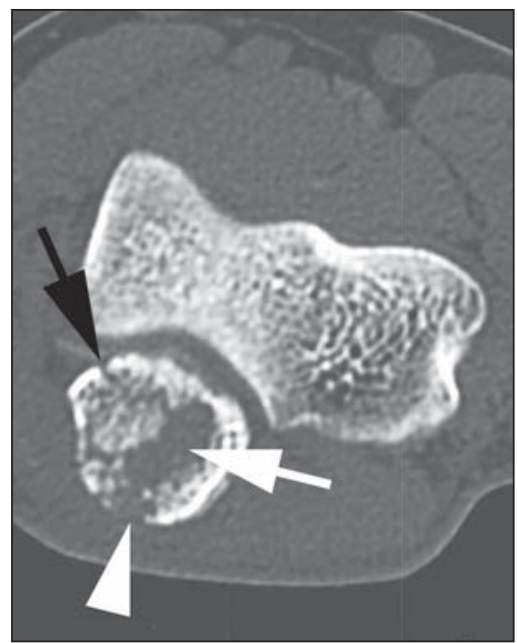

Figure 1. Male, 15-year-old adolescent with pain in the elbow for about 40 days. Elbow CT with bone window, axial section. An area of bone lysis is observed affecting the ulnar bone marrow in the olecranon process (white arrow), with signs of fracture (dark arrow), bone cortical thinning and rupture (arrowhead).

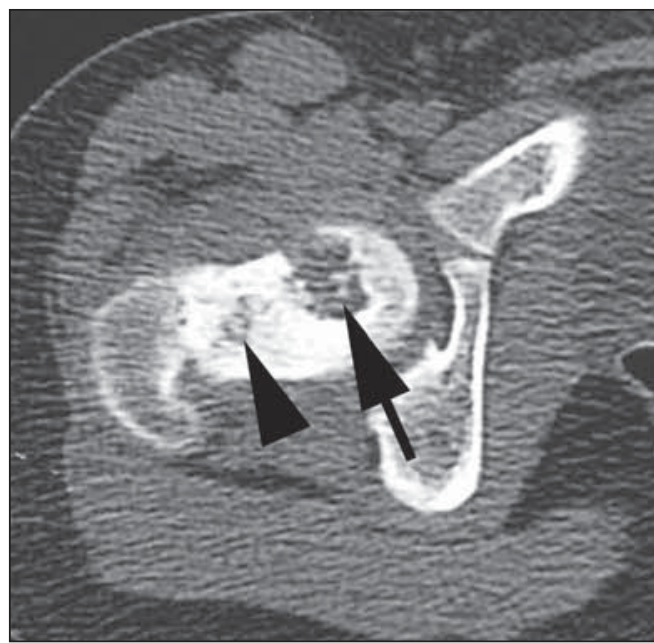

Figure 2. Male, 10-year-old young patient with history of acute knee pain. Hip CT, axial section with bone window. An area of bone lysis is observed in the femoral head (arrow) with marginal osteosclerosis associated with fracture trace in the region of the femoral head and neck (arrowhead).

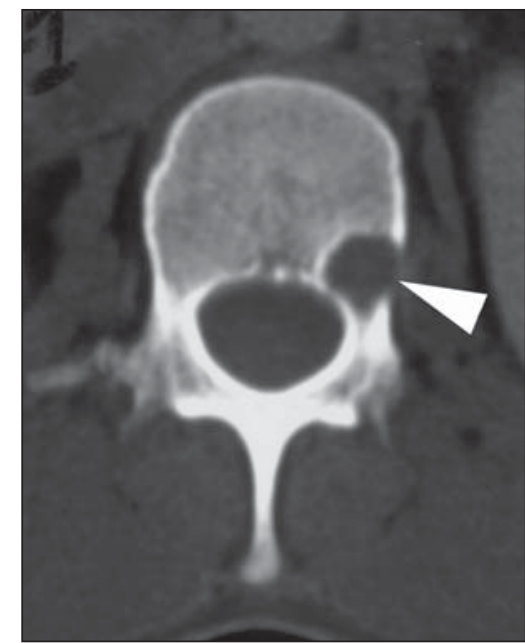

Figure 3. Male, 24-year-old patient. Thoracolum bar spine CT with bone window. A reasonably rounded area of bone lysis with fine margina osteosclerosis is observed in the vertebral body (arrowhead), extending towards the left pedicle. Percutaneous biopsy of the lesion adjacent to the L1 pedicle confirmed the diagnosis of PCM. abnormalities may eventually present cortical destruction and soft parts component mimicking bone neoplasms ${ }^{(24)}$. In the present study, such a finding was observed in $5.55 \%(1 / 18)$ of the lesions. The authors highlight the case of a child with a lesion in the intermediate cuneiform associated with an expansile mass with soft parts density (Figure 4). After contrast medium injection, the lesion showed heterogeneous, diffuse contrast-enhancement.

Studies in the literature highlight the high prevalence of lesions affecting distal clavicle extremities, sternum and ribs $^{(3,17-19,21,22)}$. As others ${ }^{(5,17)}$, the authors raise the possibility of bias resulting from the routine use of chest radiography in the initial evaluation and follow-up of PCM. The radiological investigation of other regions is initially restricted to cases with specific symptoms. In the present se-

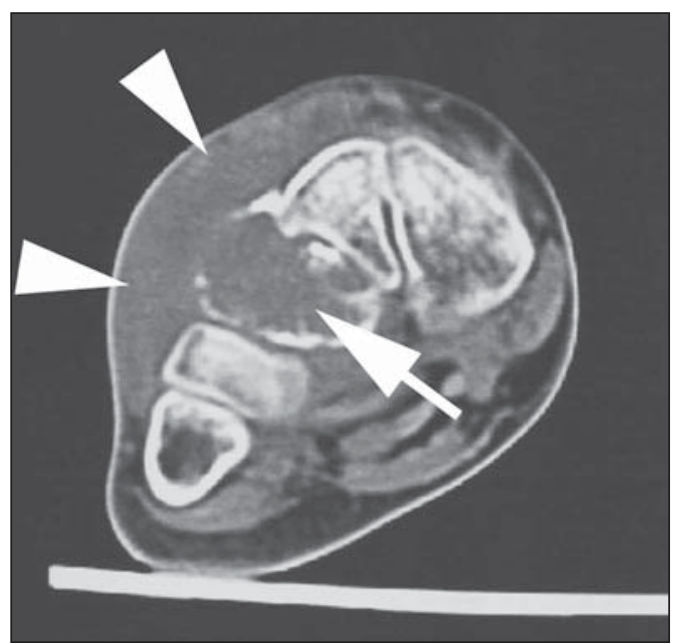

Figure 4. Female, 10-year-old patient with foot pain for three months. Coronal CT image with soft parts window. Presence of lytic lesion with cortical involvement of the intermediate cuneiform of the foot (arrow) in association with soft tissues growth (arrowheads) ries, there was one patient with symmetrical involvement of the distal third of the clavicles and acromioclavicular joints (Figure 5A), a finding that is quite suggestive of the disease according to some authors ${ }^{(3,18,19)}$.

The authors illustrate a case of bone sequestrum (Figure $5 \mathrm{~B}$ ), corresponding to presence of devitalized bone tissue separated from its matrix during the necrotic process ${ }^{(25)}$, radiologically presenting as a radiodense, in some cases sclerotic image, surrounded by a radiolucent halo representing the gap in the original bone ${ }^{(25)}$. No other report of bone sequestrum associated with PCM was found in the literature.

In PCM, bone lesions may show an insufflative appearance (Figure 5C), particularly in cases where flat bones are involved ${ }^{(18,19)}$. In the vertebral column, such lesions affect principally the vertebral bodies (Figure 3 ), and may involve the pedicles and/or extend toward the disk cartilage with end plates erosion $^{(18)}$.

The radiological aspect of the articular involvement in PCM in the present group of patients was characterized by nonspecific alterations and is in conformity com other publications ${ }^{(17-19)}$. Imaging studies can demonstrate cartilage destruction, effusion and decreased articular space.

Once the treatment is started, the bone lesions present a slow and gradual change characterized by fibrosis and neoosteogenesis, with aspect of dense and gross trabeculae $e^{(5,18,19)}$.

Opportunistic forms of PCM infection have been reported in cases of immunocompetent patients ${ }^{(26)}$, but few cases of association between PCM and HIV infection are reported in the literature ${ }^{(21,26,27)}$. Little is known about the incidence and clinical manifestations of the disease in this particular group of individuals ${ }^{(26)}$. The present series demonstrated one case of pasinus disease associated with PCM, with intranasal bone and maxillary sinus involvement in a HIV-positive patient. 

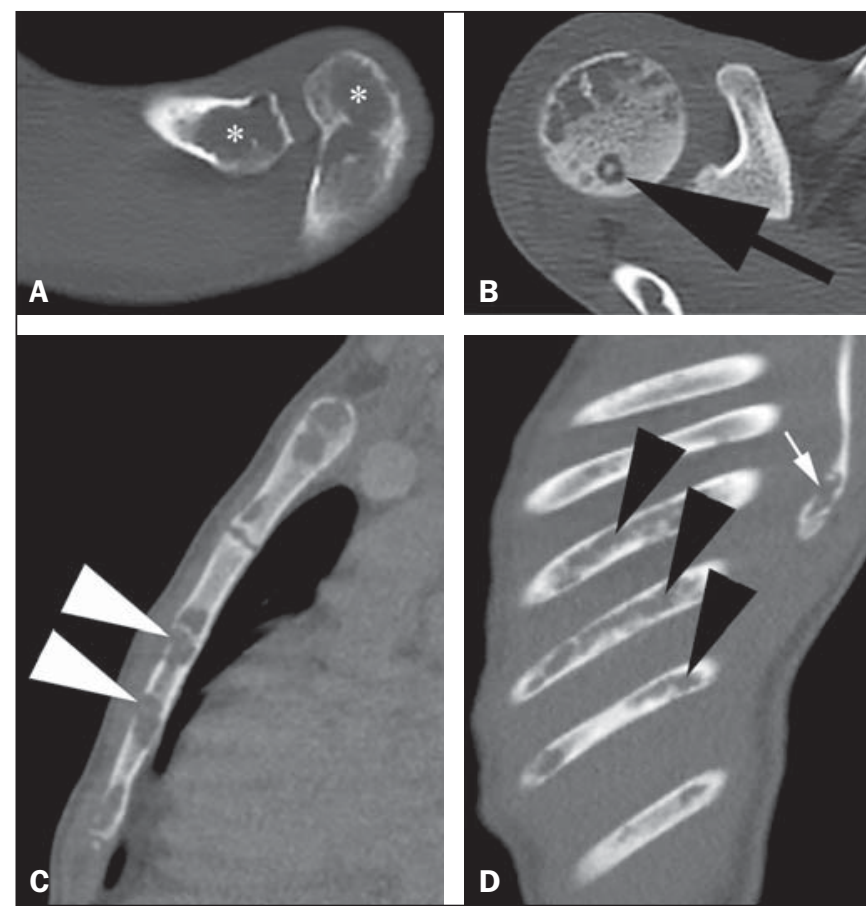

Figure 5. Male, 16-year-old patient with generalized lymph nodes enlargemen and skin lesions, presenting with multiple, sparse osteolytic lesions distributed on the humeral heads, clavicles, scapulae, sternum and costal arches. Note bone involvement in the acromioclavicular joint (asterisks on $\mathbf{A}$ ) and images of bone sequestrum on the humeral head (arrow on B). Some lesions present a slightly insufflative aspect $(\mathbf{C})$, with bone cortical rupture (arrowheads). On D, involvement of several costal arches (arrowheads), besides scapular lesion (small arrow) are observed.

Bone involvement by PCM should be included in the differential diagnosis of osteolytic lesions, even in the absence of pulmonary compromise $\mathrm{e}^{(5,21,24,28)}$, particularly in cases of individuals living in endemic areas or with history of travel to any of such places. The disease may affect individuals at any age range, frequently presenting radiological aspects indistinguishable from other conditions including chronic osteomyelitis, tuberculosis, Langerhans cell histiocytosis, multiple myeloma, lymphoproliferative disorders and metastasis ${ }^{(5,16-18,21,28,29)}$.

Equally, the articular involvement by PCM, because of its nonspecific nature, covers an extensive range of differential diagnoses, principally rheumatoid arthritis and its variants; infectious processes caused by a variety of microorganisms such as microbacteria and other fungi, sarcoidosis and, more rarely, malignant diseases such as metastatic carcinoma, lymphoma and leukemia ${ }^{(19)}$.

In cases where systemic diagnosis of the disease was not considered or in cases of diagnostic uncertainty, percutaneous biopsy might be necessary to elucidate the diagnosis.

In the present series, the authors have observed that the majority of patients submitted to CT imaging were symptomatic, which represents a selection bias. Considering that screening imaging studies in general are not indicated to detect asymptomatic PCM, it is difficult to estimate the actual prevalence of such alterations in the population with this disease.

\section{CONCLUSION}

As far the authors are concerned, this is the first study dedicated to describe CT imaging findings of bone and articular lesions in PCM.

PCM should be included in the differential diagnosis of either single or multiple osteolytic lesions either in the axial or appendicular skeleton, even in patients with no previous diagnosis of pulmonary or visceral compromise.

\section{REFERENCES}

1. Shikanai-Yasuda MA, Telles Filho FQ, Mendes RP, et al. Consenso em paracoccidioidomicose. Rev Soc Bras Med Trop. 2006;39: 297-310.

2. Wanke B, Aidê MA. Chapter 6 - Paracoccidioidomycosis. J Bras Pneumol. 2009;35:1245-9.

3. Trad HS, Trad CS, Elias Junior J, et al. Radiological review of 173 consecutive cases of paracoccidioidomycosis. Radiol Bras. 2006; 39:175-9

4. Campos MVS, Penna GO, Castro CN, et al. Paracoccidioidomycosis at Brasilia’s University Hospital. Rev Soc Bras Med Trop. 2008;41: 169-72.

5. Correa-de-Castro B, Pompilio MA, Odashiro DN, et al. Unifocal bone paracoccidioidomycosis, Brazil. Am J Trop Med Hyg. 2012;86: 470-3.

6. Michelan MS, Fernandes Ede A, Freitas LF, et al. Osteomyelitis and pyoarthritis resulting from local paracoccidioidomycosis in an immunocompetent patient: a case report. J Med Case Rep. 2012;6: 342 .

7. Silvestre MTA, Ferreira MS, Borges AS, et al. Monoartrite de joelho como manifestação isolada de paracoccidiodomicose. Rev Soc Bras Med Trop. 1997;30:393-5.

8. Moraes CS, Queiroz-Telles F, Marchiori E, et al. Review of lung radiographic findings during treatment of patients with chronic paracoccidioidomycosis. Radiol Bras. 2011 ;44:20-8.

9. Muniz MAS, Marchiori E, Magnago M, et al. High-resolution computed tomography findings in pulmonary paracoccidioidomycosis. Radiol Bras. 2002;35:147-54.

10. Freitas Filho M, Gonçalves FG, Basílio MAR, et al. Pulmonary paracoccidioidomycosis and reversed halo sign: a two-case report. Radiol Bras. 2007;40:355-7.

11. Marques SA, Cortez DB, Lastória JC, et al. Paracoccidioidomicose: frequência, morfologia e patogênese de lesões tegumentares. An Bras Dermatol. 2007;82:411-7.

12. Martinez R, Moya MJ. Primary complex of paracoccidioidomycosis and hypereosinophilia. J Bras Pneumol. 2009;35:1259-62.

13. Paniago AMM, Aguiar JIA, Aguiar ES, et al. Paracoccidioidomycosis: a clinical and epidemiological study of 422 cases observed in Mato Grosso do Sul. Rev Soc Bras Med Trop. 2003;36:455-9.

14. Bayerl JS, Oliveira ARN, Peçanha PM, et al. Osteomyelitis of the wrist in a patient with disseminated paracoccidioidomycosis: a rare presentation. Radiol Bras. 2012;45:238-40.

15. Severo LC, Agostini AA, Londero AT. Acometimento ósseo na paracoccidioidomicose crônica disseminada: relato dos primeiros casos no Rio Grande do Sul. Rev Soc Bras Med Trop. 1996;29:241-4.

16. Picado CHF, Garcia FL, Marcondes CRR. Late outcome of Paracoccidioides brasiliensis isolated infection on the hip. Acta Ortop Bras. 2006; 14:97-9.

17. Monsignore LM, Martinez R, Simão MN, et al. Radiologic findings of osteoarticular infection in paracoccidioidomycosis. Skeletal Radiol. 2012;41:203-8.

18. Costa MAB, Carvalho TN, Araújo Júnior CR, et al. Manifestações extrapulmonares da paracoccidioidomicose. Radiol Bras. 2005;38 $45-52$. 
19. Amstalden EM, Xavier R, Kattapuram SV, et al. Paracoccidioidomycosis of bones and joints. A clinical, radiologic, and pathologic study of 9 cases. Medicine (Baltimore). 1996;75:213-25.

20. Pereira RM, Bucaretchi F, Barison EM, et al. Paracoccidioidomycosis in children: clinical presentation, follow-up and outcome. Rev Inst Med Trop Sao Paulo. 2004;46:127-31.

21. de Freitas RS, Dantas KC, Garcia RS, et al. Paracoccidioides brasiliensis causing a rib lesion in an adult AIDS patient. Hum Pathol. 2010;41:1350-4.

22. Marchiori E, Dalston M, Zanetti G, et al. Paracoccidioidomycosis another cause of sternal osteomyelitis. Joint Bone Spine. 2012;79: 323-4.

23. Rosario Filho NA, Telles Filho FQ, Costa O, et al. Paracoccidioidomycosis in children with different skeletal involvement. Rev Inst Med Trop Sao Paulo. 1985;27:337-40.

24. Valera ET, Mori BM, Engel EE, et al. Fungal infection by Paracocci- dioides brasiliensis mimicking bone tumor. Pediatr Blood Cancer. 2008;50: 1284-6.

25. Jennin F, Bousson V, Parlier C, et al. Bony sequestrum: a radiologic review. Skeletal Radiol. 2011;40:963-75.

26. Paniago AM, de Freitas AC, Aguiar ES, et al. Paracoccidioidomycosis in patients with human immunodeficiency virus: review of 12 cases observed in an endemic region in Brazil. J Infect. 2005;51:248-52.

27. Marchiori E, Gasparetto EL, Escuissato DL, et al. Pulmonary paracoccidioidomycosis and AIDS: high-resolution CT findings in five patients. J Comput Assist Tomogr. 2007;31:605-7.

28. Barreto MM, Marchiori E, Amorim VB, et al. Thoracic paracoccidioidomycosis: radiographic and CT findings. Radiographics. 2012; $32: 71-84$

29. Petlik MEI, Porta G, Kiss MHB, et al. Paracoccidioidomicose generalizada com comprometimento ósseo em crianças: relato de dois casos. Pediat (S. Paulo). 1980;2:65-72. 